\title{
MENELUSURI METODOLOGI EKONOMI ISLAM ABDEL-RAHMAN YOUSRI AHMED
}

\author{
Ahmad Ubaidillah \\ Universitas Islam Lamongan \\ e-mail: ubaidmad@yahoo.com
}

\begin{abstract}
In recent years, we have witnessed a high interest in the study of methodology in the field of Islamic economics. Works in the form of books, journals, or articles on methodologies have developed rapidly over the past two decades. People's interest binding up in Islamic economics in the field of methodology is caused by several factors, among which there are those who think that the economy is not going well. Poverty still exists. Unemployment is growing along with high inflation and hardly any reliable solution to the depression of the local economy, even the regional financial crisis. Another reason for the revival of interest in the field of economic methodology is that economists, in their efforts to instill a positivistic paradigm of natural science into economics, tend to break the science of philosophy that raises ethical and moral issues relating to human goals and behavior. This paper will attempt to answer the question: what is the Islamic economic methodology offered by Abdel-Rahman Yousri Ahmed and what should the Islamic economic exponents do in the formulation of Islamic economics theory? This type of research is qualitative with the approach of figure thinking. The data collection technique is done by reading the works of AbdelRahman Yousri Ahmed and some supporting writings of the research. The result of study shows that the commitment to make the theory of Islamic economics must be realized into the form of blend between sharia rules and Islamic values into postulates or axioms. The resolving of various problems, the process of economic analysis, and the formulation of rules that explain Islamic economics, should be based on the postulates or the axioms. The empirical experience of Islamic economics is a mandatory requirement for formulating empirical theory. Islamic economics scientific theory consists of three main elements: definition or terminology, postulates (axioms or assumptions), and hypotheses. From an Islamic perspective, definitions and postulates which are composed and made in accordance with Islamic and sharia values, should be ensured to show the character of the Islamic hypothesis that culminates in the theoretical work. The historical experience of Islamic economics in the past will greatly help modern Islamic economics. The Islamic economics applicability depends heavily on using correct methodology in formulating theory.
\end{abstract}

Keywords: islamic economics methodology, Abdel-Rahman Yousri Ahmed

\section{Pendahuluan}

Setiap cabang ilmu pengetahuan pasti membahas persoalan kesejahteraan manusia yang lebih luas dari sudut pandang tertentu dan berusaha menyelesaikan saat persoalan itu muncul. Cabang ilmu ekonomi pun demikian, ia selalu mencari cara untuk memahami dan menemukan solusi atas berbagai persoalan ekonomi sebagai manifestasi perkembangan ilmu pengetahuan. Cara yang ditempuh tersebut bisa berdasarkan pada filsafat sekuler atau religius. 
Pengetahuan yang terorganisasi, termasuk ilmu ekonomi, biasanya disebut "sains" dan dibangun untuk mencapai tujuan dengan rasionalitas yang tinggi. Isu tentang sains bersifat epistemik dan apa yang disebut metodologi adalah "teori tentang teori-teori”. Dalam bidang ekonomi, ini mengacu pada proses di mana para ekonom membuktikan pengetahuan tentang fenomena ekonomi. Oleh karena itu, metodologi merupakan unsur penting dari filsafat ilmu pengetahuan.

Hubungan ekonomi dan metodologinya sama seperti hubungan antara fiqh dan ushtbalfiqh dalam tradisi keilmuan Islam. Dalam mengevaluasi kinerja ekonomi, metodologinya sama-sama deskriptif juga preskriptif. Ini menjelaskan apa yang para ekonom lakukan, seberapa baik mereka melakukannya, dan menyarankan apa yang seharusnya dilakukan.

Beberapa tahun terakhir, kita telah menyaksikan tingginya minat pada kajian metodologi di bidang ekonomi. Jumlah buku, jurnal, artikel tentang metodologi telah berkembang biak cukup cepat selama dua dekade terakhir. Ketertarikan dalam metodologi disebabkan oleh beberapa faktor, di antaranya ada yang beranggapan bahwa ekonomi tidak berjalan dengan baik. Kemiskinan masih ada. Pengangguran berkembang bersama dengan tingkat inflasi yang tinggi, dan hampir tidak ada solusi yang bisa diandalkan untuk membereskan depresi ekonomi lokal, krisis keuangan regional, bahkan global.

Faktor lain dari kebangkitan kembali minat terhadap metodologi dalam bidang ekonomi adalah para ekonom, dalam usaha mereka untuk menanamkan sebuah paradigma positivistik ilmu pengetahuan alam ke dalam ilmu ekonomi, cenderung memutus ilmu ekonomi dari filsafat yang mengangkat persoalan-persoalan etika dan moral terkait tujuan dan perilaku manusia. ${ }^{1}$

Pemikiran Islam dalam bidang ekonomi memiliki akar historis panjang dalam warisan intelektual yang tersedia dalam fiqh dan literatur yang dilahirkan oleh intekletual-intelektual muslim pada abad pertengahan. Pada masa sekarang, terutama dekade-dekade terakhir abad ke-20, kebangkitan kembali pemikiran Islam ini dibuktikan dengan lahirnya "ekonomi Islam", sebuah paradigma baru yang muncul dan berkembang dengan laju yang sangat cepat. Akan tetapi, jika kontribusi kontemporer dalam bidang ekonomi Islam ditinjau ulang, perbedaan konsep, asumsi, dan metode analisis di antara penulis ekonomi Islam bisa terlihat.

Meskipun perbedaan pendekatan dan pandangan yang memang diharapkan di antara para intelektual dalam bidang apapun, tetapi harus ada kesepakatan di antara mereka dalam hal kesamaan aliran: sebuah kesepakatan terkait persoalan-persoalan mendasar menyangkut filsafat, metodologi, dan struktur teoretis disiplin keilmuan mereka. Persoalan-persoalan penting ini, nampaknya belum bisa diselesaikan. Padahal, konsensus tentang persoalanpersoalan mendasar tersebut benar-benar dibutuhkan demi perkembangan ilmiah yang mapan. Tidak ada gunanya membicarakan paradigma dan metodologi baru jika kontroversi dan kontradiksi di antara ekonom-ekonom Islam masih dipelihara. Padahal, keadaan ini akan menghambat pertumbuhan dan kemajuan ekonomi Islam.

Ilmu ekonomi modern merupakan ilmu sekuler dan positif yang memiliki aliran pemikiran dan filsafat non islami. Dengan menggunakan metodologi yang maju dan alat

\footnotetext{
${ }^{1}$ Waleed A.J. Addas, Methodology of economics: secular vs Islamic (Malaysia: International Islamic University Press, 2008), 1-3.
} 
analisis yang mapan, ekonom modern memiliki kekayaan pengetahuan dalam hal teori dan kebijakan ekonomi. Sejauh mana ekonomi Islam dapat memanfaatkan ekonomi sekuler adalah pertanyaan yang penting. Untuk menjawab pertanyaan ini, kita perlu menjelajahi hubungnan antara ekonomi Islam dan ekonomi sekuler dan mengindentifikasi unsur-unsur yang dapat diadopsi dari ekonomi sekuler dan eleman-elemen mana yang musti ditinggalkan.

Tulisan ini akan mecoba membeberkan gagasan Abdel Rahman Yousri Ahmed tentang metodologi untuk membangun ilmu ekonomi Islam. Bagaimana pendekatan metodologis, yang menyangkut filsafat, konstruksi teoritis, dan daya terapnya yang ditawarkan Yousri Ahmed untuk ekonomi Islam adalah pertanyaan yang akan dijawab dalam tulisan ini.

\section{Biografi Singkat Abdel-Rahman Yousri Ahmad}

Abdel-Rahman Yousri Ahmad, yang memperoleh gelar PhD di bidang ekonomi pada 1968 dari Universitas St. Andrews, Skotlandia, adalah profesor dan mantan Departemen Ekonomi di Universitas Alexandria. Dia adalah mantan Direktur Jenderal International Institute of Islamic Economics di International Islam University, Islamabad, Pakistan. Dia adalah anggota Dewan Riset Ekonomi dan Akademi Penelitian dan Teknologi Ilmiah, Kementerian Pendidikan Tinggi dan Riset Ilmiah, Mesir, dan merupakan wakil profesor tamu di banyak universitas dan institut di Timur Tengah, Asia, dan Eropa. Profesor Yousri Ahmed adalah penulis sembilan buku teks dan 30 artikel, kebanyakan di bidang ekonomi Islam dan keuangan Islam. $^{2}$ Dari tahun 1968 hingga 1973, menjadi dosen Ekonomi, Fakultas Perdagangan, Universitas Alexandria. Tahun 1974 hingga 2013 menjadi anggota Staf Pengajar di Departemen Ekonomi, Fakultas Perdagangan, Universitas Alexandria, dan sejak tahun 2014 memegang jabatan permanen "Profesor Emeritus", di fakultas baru Studi Ekonomi dan Studi Politik, Universitas Alexandria, Mesir. ${ }^{3}$

\section{Perlunya Mendefinisikan Ekonomi Islam}

Definisi ekonomi Islam sudah banyak diberikan oleh ekonom-ekonom Islam. Hampir semua eksponen ekonomi Islam memberikan pandangan definitifnya masing-masing dengan penekanan yang seringkali berbeda. Begitu juga dengan tokoh yang penulis kaji dalam tulisan ini. Ia juga memiliki definisi tersendiri terkait ekonomi Islam. Menurut Yousri Ahmed, sebelum berbicara panjang lebar tentang metodologi untuk menciptakan teori-teori ekonomi Islam, pertama-tama kita perlu mendefiniskan ekonomi Islam. Yousri Ahmed mengatakan:

"Islamic Economics is the science that studies the best possible use of all available economic resources, endowed by Allah, for production of maximum possible output of hyla goods and services that are needed for the community now and in future and the just distribution of this output within the framework of sharia and its intents." 4

Yousri Ahmed lantas menjelaskan kata-kata dan ungkapan tertentu yang terdapat pada definisi tersebut. Pertama, dimensi teologis dalam definsi tersebut ditekankan dengan

\footnotetext{
2 http://www.financepractitioner.com/contributor-biographies/abdel-rahman-yousri-ahmad. Diakses pada 6 Sepetember 2017.

${ }^{3}$ http://www.hbku.edu.qa/en/staff/abdelrahman-yousri-abdelrahman. Diakses pada 6 September 2017.

${ }^{4}$ Abdel Rahman Yousri Ahmed, "Methodological Approach to Islamic Economics: Its Philosophy, Theoretical Construction and Applicability", dalam Habib Ahmed (ed), Theoretical Foundation of Islamic Economics (Jeddah: Islamic Development Bank, 2002), 28.
} 
beberapa ungkapan, seperti "ketersediaan sumber daya yang diberikan Allah SWT", "barang dan jasa yang halal", "distribusi hasil produksi secara adil", dan "dalam kerangka dan tujuan syariah". Kedua, perlu dicatat bahwa istilah "kelangkaan sumber daya ekonomi" yang digunakan dalam definisi ekonomi konvensional diganti dengan "ketersediaan sumber daya ekonomi”. Perubahan ini, menurutnya, perlu dilakukan untuk mengungkapkan berbagai kesalahpahamn yang muncul bersamaan dengan sejumlah penulis ekonomi Islam dikarenakan menjelaskan "sumber daya" sebagai barang langka. Kelangkaan relatif diakui dalam Islam, dan ungkapan "ketersediaan sumber daya", sama sekali Islam tidak menolaknya. Produksi barang dan jasa semaksimal mungkin yang dibutuhkan oleh masyarakat, dalam definisi tersebut, menunjukkan bahwa ketersediaan sumber daya tidaklah cukup menghasilkan barang dan jasa yang mampu memenuhi semua kebutuhan masyarakat. Inilah, menurut Yousri Ahmed, hakikat kelangkaan relatif.

Barang dan jasa halal adalah barang dan jasa yang diperbolehkan oleh Syariah. Hal ini menegaskan bahwa sumber daya ekonomi yang diberikan oleh Allah SWT harus hanya digunakan untuk pemuasan kebutuhan yang diizinkan Allah SWT. "Keadilan" adalah tujuan utama syariah. "Distribusi yang adil" atas output harus mencerminkan definisi ekonomi Islam. Ungkapan "dalam kerangka dan tujuan syariah" dalam definisi tersebut mempunyai berbagai implikasi. Pertama, hanya barang dan jasa halal yang akan diproduksi. Kedua, semua kegiatan ekonomi yang menyangkut kontrak dan transaksi harus sesuai dengan syariah. Ketiga, distribusi ouput di antara umat Islam harus sesuai dengan syarat-syarat keadilan dan tujuan-tujuan syariah. Keempat, pemuasan kebutuhan di masa depan dipenuhi dengan batasan-batasan eksploitasi wajar, pemeliharaan dan pengembangan segala macam sumber daya. Di tempat lain, Yousri Ahmed memberikan definisi ekonomi Islam agak mirip sebagai:

"Ilmu yang mengkaji kemungkinan penggunaan seluruh sumber daya produktif manusia, sumber daya alam, dan sumber daya buatan manusia, untuk mendaptkan penghasilan yang halal di masa sekarang dan masa depan, kemudian mendistribusikan dan mengeluarkan penghasilan tersebut dalam kerangka syariah". 5

Yousri Ahmed memberikan saran kepada ekonom-ekonom Islam agar mematuhi dan berpegang teguh pada kerangka hukum Islam dengan aturan-aturan syariahnya. Ia juga memperingatkan agar memasukkan nilai-nilai Islam dalam analisisnya, dan pada saat yang sama, mengabaikan ekonomi konvensional ketika diperlukan.

Ada pemikiran yang berkembang di sebagian kalangan bahwa prinsip-prinsip syariah atau hukum ekonomi Islam itu sama dengan ekonomi Islam. Pernyataan ini segera dibantah oleh Yousri Ahmed dengan mengatakan bahwa tidaklah benar menyamakan prinsip-prinsip dan nilai-nilai Syariah terkait transaksi ekonomi dengan ekonomi Islam. Aturan-aturan Syariah memberikan prinsip-prinsip bertindak dan membentuk kerangka yang mengikat. Kita, sebagai ekonom-ekonom Islam, tidak bisa melampaui prinsip-prinsip ini dengan mengubahnya, dengan menggunakan kecerdasan intelektual kita untuk mencocokkan dengan tujuan kita sendiri. Tegasnya, kita musti memahami bagaimana mengikuti kerangka syariah ini dalam analisis ekonomi Islam.

\footnotetext{
${ }^{5}$ Ibid., $28-30$.
} 
Pendekatan ilmiah yang benar, menurut Yousri Ahmed, perlu memasukkan prinsipprinsip Syariah dan motif-motif religius ke dalam aksioma-aksioma ${ }^{6}$. Ini bisa dilakukan saat mengkaji persoalan atau fenomena. Dalam hal ini, kita mengandalkan kemampuan intelektual kita dan pengalaman praktis untuk menggunakan aksioma-aksioma ini dalam mengkaji dan menganalisis persoalan praktis ekonomi. Yousri Ahmed kemudian memberikan contoh pelarangan riba. Postulat ${ }^{7}$ yang tidak bisa disangkal datang dari Allah dengan firman-Nya.

\section{“Allah SWT menghalalkan jual beli dan mengharamkan riba"}

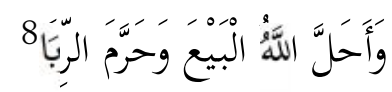

Agar bisa sesuai dengan ayat dalam analisis ekonomi, kita tidak harus "membuka pintu" untuk pendapat pribadi. Kita perlu konsep ekonomi yang obyektif dan jelas yang mempertimbangkan praktik riba yang dikenal di masa kita. Ketika ini sudah dilakukan, kita bisa merumuskan postulat terkait riba untuk menganalisis persoalan keuangan dan transaksi moneter dalam kerangka Islam. ${ }^{9}$

Pertanyaan kita sekarang adalah bisakah ekonomi Islam dikembangkan dengan mengambil manfaat dari ekonomi konvensional? Jika memungkinkan, sampai sejauh mana jaungkauan dan batasannya? Dalam konteks pendekatan ilmiah, Yousri Ahmed mengatakan bahwa manfaat yang mungkin bisa dipetik dari ekonomi konvensional bisa dikelompokkan ke dalam manfaat yang bersifat pendidikan (educational gains) dan manfaat yang bersifat analisis (analytical gains).

Pertama, manfaat yang bersifat pendidikan. Ini bisa diperoleh dengan mengkaji teoriteori ekonomi konvensional untuk mengetahui bagaimana teori-teori tersebut berkembang, merespon persoalan-persoalan ekonomi yang berlangsung dari waktu ke waktu. Kita perlu mengkaji bagaimana persoalan-persoalan ini dikaji dalam konteks asumsi atau postulat yang menggambarkan filsafat sekuler di satu sisi, dan kondisi praktis yang ada di sisi lain. Jika ini bisa dipahami, kita bisa mendapatkan gagasan bagaimana menganalisis dan memberikan solusi atas persoalan-persoalan ekonomi yang kita hadapi saat ini dari perspektif Islam.

Manfaat lainnya yang bisa kita ambil dari ekonomi konvensional, menurut Yousri Ahmed, adalah memahami hubungan antara asumsi atau postulat yang diberikan dalam teori dan filsafat sekuler. Memahami hubungan ini bisa digunakan untuk mengembangkan ekonomi Islam. Postulat atau asumsi yang dasar filosofis dan landasan praktisnya tidak sesuai dengan prinsip-prinsip dan nilai-nilai Islam otomatis akan ditolak. Postulat atau asumsi yang dasar

\footnotetext{
${ }^{6}$ Aksioma dapat didefinisikan sebagai suatu pernyataan dasar yang tidak dapat disimpulkan dari pernyataanpernyataan lain. Aksioma merupakan titik awal dari mana pernyataan-pernyataan lain dapat disimpulkan. Aksioma-aksioma dapat dibuktikan dengan cara yang sama sebagaimana pernyataan-pernyataan lain yang disimpulkan dari aksioma-aksioma. Lihat Lorens Bagus, Kamus Filsafat (Jakarta: Gramedia Pustaka Utama, 2000), 34. Dengan kata lain, aksioma adalah kebenaran yang tak perlu diragukan lagi kebenarannya karena telah disetujui oleh semua.

${ }^{7}$ Postulat adalah anggapan dasar atau landasan berpikir atau premis dari rangkaian pemikiran dan belum tentu jelas sehingga perlu pembuktian lebih lanjut. Lihat Pius A Partanto dan M. Dahlan Al-Barry, Kamus Ilmiah Populer (Surabaya: Penerbit Arkola, 1994), 613.

8 al-Quran, 2: 275.

${ }^{9}$ Abdel Rahman Yousri Ahmed, "Methodological Approach", 30-32.
} 
dan karakernya berbeda, namun tidak bertentangan dengan nilai-nilai Islam, bisa kita rubah, sesuaikan, dan terima jika memang ini berguna. ${ }^{10}$

Kedua, manfaat yang berifat analisis. Ekonomi Islam, dalam hal ini, bisa juga mengambil manfaat dari ekonomi konvensional dengan mempelajari alat analisis yang digunakan oleh ekonomi konvensional. Alat-alat ini menyangkut teknik, yang berkaitan dengan pengembangan skill dan pengalaman atas persoalan ekonomi yang berbeda, misalnya klasifikasi, analisis, atau bagaimana mengukur variabel. Contoh alat analisis ini adalah pembagian fenomena ekonomi ke dalam bentuk ekonomi mikro dan mikro, atau perbedaan antara variabel independen dan dependen. Teknik analisis juga menyangkut penggunaan matematika, statistik untuk mendapatkan hasil yang akurat. Perlu dicatat, teknik analisis ini bersifat netral, yang tidak bercampur dengan konsep, asumsi, postulat, atau dalam merumuskan hipotesis. Untuk mempelajari teknik analisis ini, dan untuk mengembangkan ketangkasan menggunakan teknik-teknik tersebut, pengkaji ekonomi Islam perlu mempelajari karya-karya penelitian terbaru ekonomi konvensional. ${ }^{11}$

\section{Metodologi Abdel Rahman Yousri Ahmed}

Yousri Ahmed menyadari bahwa perumusan teori ekonomi memang bukan tugas yang mudah. Ini adalah pekerjaan berat. Teori ekonomi konvensional berkembang dalam konteks filosofis selama waktu yang panjang dalam merespon perskembangan persoalan-persoalan ekonomi. Teori tersebut juga telah berkembang dengan canggih bersama dengan perkembangan alat analisis dan melalui kontribusi para sarsjana dan pemikir. Tidaklah mungkin bagi seorang ekonom merumuskan sendiri teori yang bisa bertahan dalam perubahan yang terus-menerus dalam kehidupan ekonomi tanpa kualifikasi, sedangkan pengalaman analisis dalam disiplin tesebut mengalami perkembangan. Yousri Ahmed menawarkan langkah-langkah untuk merumuskan teori ekonomi Islam yang dibagi menjadi dua bagian, yaitu prakondisi dan konstruksi.

\section{Prakondisi}

Pertama, terdapatnya mujtahidiæ (jamak dari mujtahid). Eksistensi mujtahidi sangat diperlukan karena tidak ada kemajuan yang bisa diciptakan tanpa keberadaan meraka. Mereka adalah anugerah Tuhan untuk masyarakat Islam. Pintu-pintu akan terbuka untuk kemajuan ilmiah ketika sejumlah mujtahid muncul, memainkan peran besar. Untuk memberikan kontribusi terhadap ekonomi Islam, para mujtahid harus memliki dua jenis ilmu pengetahuan. Di satu sisi, mereka harus memiliki pemahaman yang komprehensif tentang prinsip-prinsip yang mengatur semua aspek ekonomi, yang secara langsung atau tidak langsung, berasal dari al-Quran dan Sunnah dan juga pengetehuan tentang kontribusi para ahli hukum Islam dan sarjana muslim sebelumnya. Di sisi lain, mereka harus memiliki pengetahuan ekonomi konvensional untuk menggali prinsip-prinsip ekonomi konvesional yang sesuai dengan nilainilai syariah. Mujtahid pada prinsipnya merupakan intelektual yang mampu memperkenalkan secara mandiri "aturan-aturan baru" atau gagasan-gagasan yang bermanfaat bagi umat Islam, dalam tempat dan waktu tertentu, yang sesuai dengan aturan-aturan syariah yang murni.

\footnotetext{
${ }^{10}$ Ibid., 34.

${ }^{11}$ Ibid., 37.
} 
Ekonomi Islam akan mengalami kemajuan dengan cepat jika para mujtahid benar-benar menjadi pembaharu, bukan peniru. ${ }^{12}$

Kedua, suasana Islam yang baik. Keadaan politik, sosial, budaya Islam yang melindungi, memudahkan, dan mendorong para mujtahid untuk memproduksi gagasangagasan dan aturan-aturan baru dan mengembangkan penelitian ilmiah merupakan syarat penting untuk kemajuan ekonomi Islam dalam jangka panjang. Perlu diingat bahwa dalam upaya di bidang ini, tidak akan didukung atau dipuji oleh mereka yang mengadopsi filsafat dan budaya Barat serta sistem sekuler. Selain itu, menurut Yousri Ahmed, kondisi budaya dan sosial harus mendukung bagi pendidikan Islam di semua tingkat dan bagi penelitian ekonomi Islam. Ekonomi Islam harus diberikan perhatian yang seharusnya di universitas sebagai syarat akademik, dan para peneliti harus didorong untuk memberikan kontribusinya untuk disiplin baru ini. Lingkungan semacam ini akan meningkatkan kontribusi para mujtahid yang kompeten dan akan meningkatkan peneliti-peneliti ekonomi Islam yang kompeten, loyal dan bersungguh-sungguh.

Ketiga, pengalaman empiris ekonomi Islam. Muncul dan tumbuhnya pengalaman empiris ekonomi Islam, apakah di tingkat makro atau mikro, merupakan syarakat penting yang menyempurnakan dua prasyarat sebelumnya. Pengalaman merupakan dasar atau pokok ilmu positif atau empiris. Teori ekonomi konvensional adalah positif. Teori positif harus diverifikasi dan diuji dalam praktik untik menilai validitasnya. Tugas ini, menurut Yousri memerlukan pengumpulan data tentang fenomena atau persoalan ekonomi khusus yang memungkinkan teori-teori tersebut menjelaskan melalui hipotesis. Menurut Yousri Ahmed, pengalamn empiris ekonomi Islam modern saat ini tidaklah cukup. Pada tingkat makro, hanya tiga negara (Pakistan, Iran dan Sudan) yang telah menerapkan sistem ekonomi Islam secara penuh. Implementasi tujuan ini pun dirasa belum sempurna.

Yousri Ahmed menegaskan bahwa pengalaman empiris ekonomi Islam merupakan syarat penting untuk membangun teori ekonomi Islam. Para eksponen gagasan ini dipengaruhi oleh konseps ilmu empiris modern. Tidak ada seorang pun yang bisa mengabaikan signifikansi penelitian ilmiah. Dalam arti. kita tidak bisa mengabaikan pentingnya metode deduksi dan peranan utamanya dalam pengembangan teori ekonomi. Pengujian atas hipotesis dapat dimulai dengan memeriksa implikasi eksperiensial dari hipotesis. Setelah seorang ilmuwan memilih hipotesis, langkah berikutnya adalah menyimpulkan prediksi-predisksi eksperiensial dari hipotesis itu, mencatat dan menyeleksi prediksi-prediksi serta pada akhirnya mengamati apakah prediksi itu terjadi atau tidak. Proses menarik prediksi-prediksi dari suatu hipotesis inilah kita sebut proses deduksi. ${ }^{13}$

Menurut Simon dan Burstein, sebagaimana yang dikutip oleh Yousri Ahmed, deduksi merupakan metode yang sangat berguna untuk meningkatkan pemahaman kita tentang dunia, khususnya dalam dua kondisi. Pertama, kita mengetahui logika beberapa fenomena, namun memiliki sedikit informasi tentangnya, dan kedua, kita memiliki sejumlah informasi tentang

\footnotetext{
${ }^{12}$ Ibid., 38-39.

${ }^{13}$ A. Sonny Keraf dan Mikhael Dua, Ilmu Pengetahuan: Sebuah Tinjauan Filosofis (Yogyakarta: Kanisius, 2001), 97.
} 
sesuatu namun kita tidak mampu memahaminya. Metode deduksi memainkan peranan yang sangat penting dalam peciptaan teori ekonomi Islam di masa sekarang. ${ }^{14}$

Dapatlah dikatakan bahwa teori ekonomi Islam akan diverifikasi berdasarkan pengalaman aktual. Namun pada saat yang sama, tidaklah bijak untuk menunda penciptaan teori ekonomi Islam hingga kita bisa melakukan kajian-kajian empiris. Mengembangkan teori dengan metode deduksi, yang mempertimbangkan aturan dan etika Islam, akan sangat membantu kita mengidetifikasi "apa yang seharusnya" dan menemukan cara untuk mencapai tujuan yang telah ditentukan.

\section{Langkah-langkah (Konstruksi)}

Teori ilmiah dalam bidang ekonomi, dan di bidang ilmu-ilmu yang lain dibentuk dari tiga unsur pokok, yaitu definisi atau terminologi; postulat/aksioma/asumsi; dan hipotesis. Perumusan teori dari tiga unsur pokok ini dilakukan sebagaimana yang ditunjukkan dalam gambar berikut:

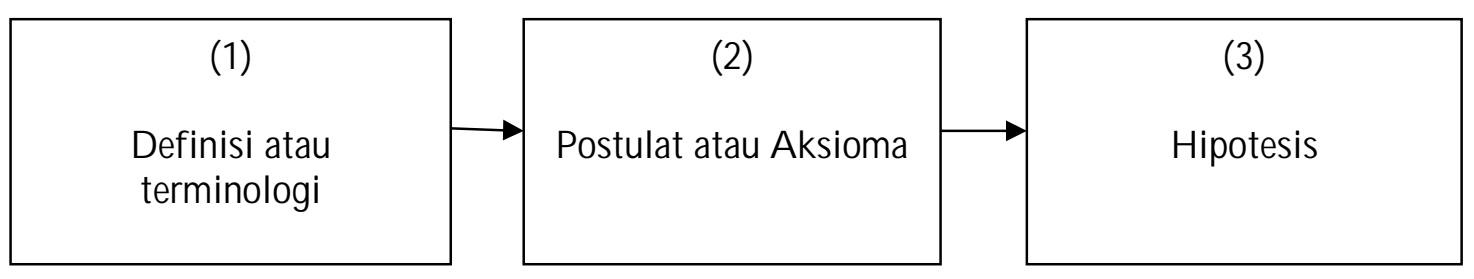

Pertama, definisi atau terminologi. Pada bagian terdahulu, Yousri Ahmed sudah sudah menunjukkan kepada kita bahwa ilmu ekonomi konvensional dapat memberikan manfaat untuk ekonomi Islam. Namun, perlu juga diperhatikan bahwa kebanyakan definisi atau terminologi yang digunakan dalam ekonomi konvensional sangat terkait dengan karakteristik yang menyertai dan mempengaruhi perkembangan ilmu ekonomi konvensional. Di antara ciri penting ekonomi konvensional adalah obsesinya pada realisme, filsafat matrialistis, orientasi pada abstraksi, dengan memisahkan perilaku ekonomi dari faktor-faktor manusia yang mempengaruhinya. Di sinilah menurut Yousri Ahmed, ijtihad diperlukan untuk meneliti dan menentukan apakah definisi teori ekonomi sekuler (konvensional) dapat dipakai dalam ekonomi Islam atau tidak. Definisi atau terminologi yang tidak bertentangan dengan prinsipprinsip Islam dapat digunakan. Dalam hal ini, Yousri memberikan contoh.

Maksimalisasi utilitas merefleksikan perilaku rasional dalam teori konsumsi ekonomi neoklasik. "Utiliti" dan "perilaku rasional" memiliki makna linguistik yang berbeda dari konsep ekonominya. Istilah-sitilah ini mungkin menipu jika seseorang tidak mengetahui makna ekonomi tententu berserta implikasinya. Dalam pemikiran Barat, konsep utilitas dikembangkan sebagai "moralitas yang baik" yang berkaitan dengan kepentingan pribadi sebagaimana diyakini oleh individu itu sendiri. Kata "baik" tidak memiliki makna universal, namun bersifat relatif tergantung apa yang dipikirkan individu dalam mencapai kepentingannya meskipun ini secara moral merugikan orang lain atau tidak sehat bagi tatanan ekonomi. Jadi, perilaku rasional didefinisikan sebagai maksimalisasi kepentingan individu. Konsep dan definisi ini tidak sesuai dengan nilai dan moralitas Islam. Definisi dalam teori

\footnotetext{
${ }^{14}$ Abdel Rahman Yousri Ahmed, "Methodological Approach”, 39-40.
} 
ekonomi Islam harus secara hati-hati memilih istilah-istilah atas dasar linguistik dan kemudian secara jelas mendefinisikan makna Islamnya. Yousri Ahmed memperingatkan kita bahwa pemahahamn teori apapun, konsekuensi dan penggunaannya akan selalu bergantung pada definisi yang dianjurkan oleh pencetusnya. ${ }^{15}$

Kedua, Postulat/aksioma/asumsi. Postulat harus mencerminkan prinsip-prinsip dan nilai-nilai Syariah yang berkaitan dengan persoalan ekonomi. Postulat-postulat ini lalu digunakan sebagai istilah-istilah pengikat dalam perumusan hipotesis. Ekonomi Islam mencakup aspek normatif ${ }^{16}$ dan oleh karena itu, postulat-postulat tersebut akan menggambarkan aspek-aspek normatif tersebut. Yousri Ahmed memberikan contoh kasus perusahaan yang terkait dengan postulat-postulat normatif berikut ini:

1. Produksi barang-barang harus sesuai dengan syariah Islam. Jadi, hanya barang-barang yang diizinkan Allah SWT yang bisa diproduksi.

2. Target produksi perusahaan memang ditentukan oleh kepentingan pribadi, namun mempertimbangkan kepentingan publik. Jika ada pertentangan di antara dua kepentingan, kepentingan publik akan diutamakan. Fungsi sosial kepemilikan pribadi dalam keyakinan Islam dan aturan-aturan syariah sangat diutamakan.

3. Perusahaan tidak harus mengikuti kebijakan produksi retriktif atau terlibat kesepakatan eksplisit atau implisit apapun dengan produsen lain untuk membatasi persediaan/penawaran dan mempengaruhi harga pasar. Dengan kata lain, monopoli dan parktik monopolistik sangat dilarang.

4. Perusahaan tidak harus mempengaruhi harga secara langsung dengan menciptakan jumlah barang. Perusahaan juga tidak seharusnya menurunkan kualitas untuk mencapai keuntungan tambahan. Larangan perilaku curang.

5. Perusahaan harus menjamin hak-hak pekerja sesuai dengan aturan di pasar tenaga kerja dan tidak harus mengikuti cara monopostik dalam bentuk apapun dalam menjual produknya. Para pekerja harus diberikan upahnya tepat waktu. Bertransaksi dengan penjual sebelum tiba di pasar dilarang.

Prinsip-prinsip syariah ini harus bisa dinyatakan dalam postulat. Contoh yang diberikan di atas menekankan pentingnya kepatuhan kepada petunjuk dan hukum-hukum syariah dalam merumuskan teori perusahaan.

Selanjutnya, Yousri Ahmed menunjukkan kepada kita bagaimana merumuskan postulat yang berdasarkan pada penelitian aktual dan data empiris. Ini sangat penting ketika ada pengalaman empiris ekonomi Islam dan padangan positif harus digambarkan. Sebelum melangkah lebih jauh, pertanyaan yang perlu diajukan adalah haruskah kita berpegang teguh pada observasi-observasi ini, sebagaimana dalam kasus ekonomi konvensional positif? Bersikap hati-hati atas kondisi realitas yang mungkin bertentangan atau tidak bertentangan dengan konsep normatif yang digambarkan dalam postulat-postulat lain adalah jawabannya. Dengan kalimat lain, dalam kondisi yang ideal, ketika sistem ekonomi Islam secara penuh

\footnotetext{
${ }^{15}$ Ibid., 40-41.

${ }^{16}$ Dalam ilmu ekonomi, istilah normatif dibedakan dengan positif. Ilmu ekonomi normatif adalah ilmu yang berdasrkan pada suatu penilaian, mengajukan pandangan atau pernyataan-pernyataan tentang apa atau bagaimana yang "sebaiknya" atau "seharusnya" terjadi. Sedangkan ilmu ekonomi positif adalah ilmu ekonomi yang berdasarkan fakta-fakta, kenyataan, lingkungan, dan hubungan dalam perekonomian mengutarakan "apa adanya”. Lihat T. Gilarso, Pengantar Ilmu Ekonomi Makro (Yogyakarta: Kanisius, 2004), 43.
} 
diterapkan, observasi aktual seharusnya tidak bertentangan dengan postulat normatif yang digali dari Syariah. Akan tetapi penilaian ini hanya akan terwujud dalam keadaan ideal. Dalam sejarah Islam, kita bisa menemukannya hanya pada masa Nabi Muhammad SAW dan empat khalifah. Upaya masa depan di negara-negara muslim menuju pembaharuan Syariah Islam dalam segala aspek kehidupan diharapkan mempersempit jurang antara "apa yang seharusnya" dan "apa adanya".

Saat ini, menurut Yousri Ahmed, kita harus menyadari celah (gap) antara aspek normatif dan kondisi aktual dalam perekonomi umat Islam. Celah ini sangat besar. Jika mengandalkan kondisi aktual dalam merumuskan asumsi untuk teori kita, kemunkinan besar kita tidak menemukan perbedaan antara perekenomian konvensional dan perekonomian Islam. Celah semacam ini, menurutnya, bisa dibenarkan syariah dengan alasan dłłruðah, yang agaknya dapat dibenarkan untuk perubahan dari kondisi di mana prinsip-prinsip syariah tidak diterapkan, atau sebagaian diterapkan, ke dalam kondisi di mana prinsip-prinsip syariah diterapkan. Dalam kasus dłłruðah, kita mungkin masih bisa merefleksikan kondisi aktual sebagai asumsi realistis bersama dengan postulat yang berasal dari nilai-nilai dan prinsipprinsip syariah. Teori yang dibangun dari "campuran" ini hanya akan valid dan bisa dikembangkan ketika perubahan ekonomi masyarakat menuju pada "apa yang seharusnya". ${ }^{17}$

Ketiga, Hipotesis. Dalam metode empiris, hipotesis dirumuskan melalaui "induksi enumeratif" yang disimpulkan bahwa apa yang benar untuk "sejumlah kasus yang diamati" yang berkaitan dengan fenoemana tertentu yang dianggap benar untuk semua jenis kasus. ${ }^{18}$ Cara kerja metode induksi yang secara sistematis dimulai dari pengamatan secara teliti gejala yang sedang diselidiki. Pengamatan berulang-ulang ini akan memperlihatkan adanya ciri-ciri umum yang dirumuskan menjadi hipotesis. Selanjutnya, hipotesis itu dikukuhkan dengan cara menemukan bukti-bukti empiris yang dapat mendukungnya. Hipotesis yang berhasil dibenarkan (dijustifikasi) akan berubah menjadi hukum. ${ }^{19}$ Hipotesis akan mempertimbangkan kondisi yang ada di sekitar fenomena melalui asumsi yang berdasarkan pada observasi, dan mengidentifikasi faktor-faktor utama yang mempengaruhinya untuk bisa dijelaskan. Jadi, hipotesis akan memungkinkan kita mengidentifikasi faktor-faktor yang akan menyebabkan peristiwa tertentu terjadi dan memprediksi akibatnya. Metode ini dapat digunakan untuk merumuskan teori ekonomi Islam hanya ketika ada pengalaman aktual di mana data bisa dikumpulkan.

Dalam hal ini, Yousri Ahmed memberikan contoh. Kita bisa mengumpulkan data tentang bank-bank Islam pada saat ini dan untuk merumuskan hipotesis yang berkenaan dengan dampaknya pada investasi dalam sejumlah kasus tertentu. Demikian pula, data tentang zakat dapat dikumpulakan untuk mempelajari dampaknya pada distribusi pendapatan atau pada konsumsi kelompok berpendapatan rendah. Data tentang zakat tersedia di sejumlah tempat, misalnya data resmi pemerintah. Namun, data tersebut lebih banyak terdapat di masyarakat religius dan pundi amal pribadi di tingkat lokal. Perlu diingat bahwa karena tempat-tempat yang yang bisa diamati jumlahnya terbatas, ini akan bisa dicapai melaui metode empiris yang tentu saja tidak bisa digeneralisasi secara tepat dan benar. Tetapi

\footnotetext{
${ }^{17}$ Abdel Rahman Yousri Ahmed, "Methodological Approach", 41-43.

${ }^{18}$ Ibid., 43.

${ }^{19}$ Surajiyo, Filsafat Ilmu dan Perkembangannya di Indonesia, cet-7 (Jakarta: Bumi Aksara, 2013), 96.
} 
bagaimanapun juga, menggantungkan pada metode deduksi dengan kerja empiris untuk memperoleh beberapa kesimpulan yang meyakinkan dan layak sangatlah penting. Terlepas dari dari kasus ini, di mana hanya sedikit informasi yang tersedia, ada banyak kegiatan ekonomi di negara-negara muslim yang menyimpang dari prinsip-prinsip syariah yang tidak cocok dengan data empiris untuk mengisi tujuan ekonomi Islam.

Yousri Ahmed juga menekankan pentingnya deduksi dan mengingatkan mereka yang hanya menggunakan metode induksi. Banyak ekonom klasik dan neo-klasik menggunakan metode deduksi untuk memperoleh aturan dan prinsip guna menginterpretasikan fenomena ekonomi dan merumuskan teori ekonomi yang masih bertahan hingga sekarang. Teori keunggulan komparatif David Ricardo yang dirumuskan pada 1817 adalah contohnya. Selain itu, sangatlah perlu melakukan penelitian empiris untuk memperkuat validitas teori-teori tersebut. Melakukan tahapan pengujian empiris pada tahap selanjutnya tidak hanya perlu untuk ekonomi Islam, tetapi juga berguna bagi perkembangan ekonomi Islam di masa depan. $^{20}$

\section{Peranan Sejarah Ekonomi dalam Analisis dan Penelitian}

Dalam merumuskan teori-teori ekonomi Islam, apakah cukup kita mengandalkan metode deduksi dan induksi saja? Menurut Yousri Ahmed, analisis teoritis (metode deduksi dan metode induksi) memang alat yang sangat penting untuk penelitian ekonomi Islam, tetapi bukan satu-satunya alat. Ada alat-alat penting lainnya, yaitu sejarah ekonomi. Sejarah ekonomi, menurutnya, apakah sejarah ekonomi saat ini atau masa lalu, menggambarkan pengalaman ekonomi, yang hasil dan dimensinya menjadi fakta yang telah diketahui. Sejarah ekonomi dapat digunakan dalam proses analisis dengan meninjau ulang peristiwa-persitiwa dan rentetan waktunya untuk memahami penyebab dan dampaknya. Meskipun peristiwa ekonomi tidak mengulang dirinya sendiri, namun mempelajari logika "mengapa peristiwa terjadi" dan konsekuensinya dapat berguna dalam menjelaskan peristiwa lainnya dari sifat yang sama dan membuat perkiraan-perkiraan tentang kemungkinan efeknya. Inilah esensi logika sejarah ekonomi. Kita bisa memahami penyebab peristiwa terjadi dari sejarah.

Kajian persoalan ekonomi melauli sejarah juga mengungkapkan hubungan antara persoalan dan fenomena lain. Dalam hal ini, ekonomi Islam, sebagai paradigma baru bisa mengambil banyak manfaat dari pengalaman sejarah Islam di masa lalu. Pentingnya "logika sejarah" dalam analisis ekonomi, menurut Yousri Ahmed, dapat ditunjukkan dengan meninjau ulang beberapa karya Ibnu Khaldun misalnya. Ibnu Khaldun menjelaskan perkembangan perdaban berdasarkan kemajuan kebutuhan manusia dan bagaimana ini bisa bertemu di bawah kondisi sejarah yang berbeda. Pertumbuhan produksi menghasilkan analisisnya dari pertumbuhan penduduk dan kebutuhannya, pembagian tenaga kerja, dan kecerdsan manusia yang dikombinasikan dengan usaha-usaha produktif.

Selain Ibnu Khladun, Yousri Ahmed juga merujuk pada al-Maqrizi, sejarahwan terkemuka dan pengikut cerdas Ibnu Khaldun. Al-Maqrizi juga memberikan pertimbangan besar terhadap faktor-faktor historis dalam menganalsis alasan terjadinya hiperinflasi yang dia saksikan selama hidupnya di Mesir. Dengan menggunakan bukti-bukti historis dan

\footnotetext{
${ }^{20}$ Abdel Rahman Yousri Ahmed, "Methodological Approach", 43-44.
} 
menjelaskan logikanya, dia mampu menemukan bahwa kekuatan-kekuatan alam dapat menyebabkan fluktuasi siklis dalam hasil panen pertanian dan imbasnya pada harga. ${ }^{21}$

Bagi sarjana muslim, yang membaca al-Quran, tentu tidak mengherankan karena Allah di banyak ayat, mendorong umat Islam untuk mempelajari sejarah dan memikirkan serta menyadari logika persistiwa sejarah. Misalnya:

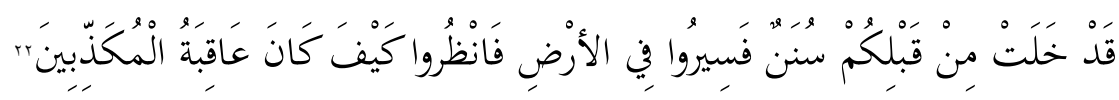

"Sesungguhnya telah berlalu sebelum kamu sunnah-sunah Allah. Karena itu berjalanlah kamu di muka bumi dan perhatikanlah bagaimana akibat orang-orang yang mendustakan (rasul-rasul)".

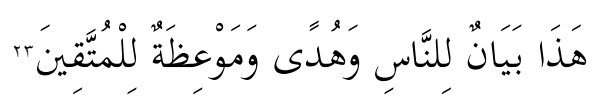

“Al-Quran ini adalah penerangan bagi seluruh manusia, dan petunjuk serta pelajaran bagi orang-orang yang bertakwa".

Beberapa pengalaman bangsa-bangsa masa lau yang disebutkan al-Quran sangat terkait dengan peristiwa ekonomi. Misalnya:

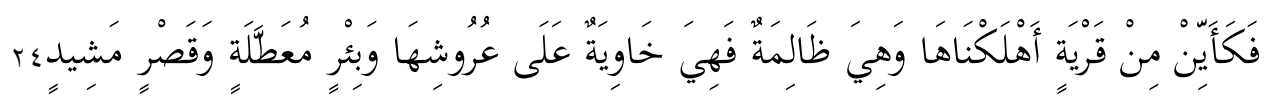

"Berapa banyak kota yang Kami telah membinasakannya, yang penduduknya dalam keadaan lalim, maka (tembok-tembok) kota itu roboh menutupi atap-atapnya dan (berapa banyak pula) sumur yang telah ditinggalkan dan istana yang tinggi”.

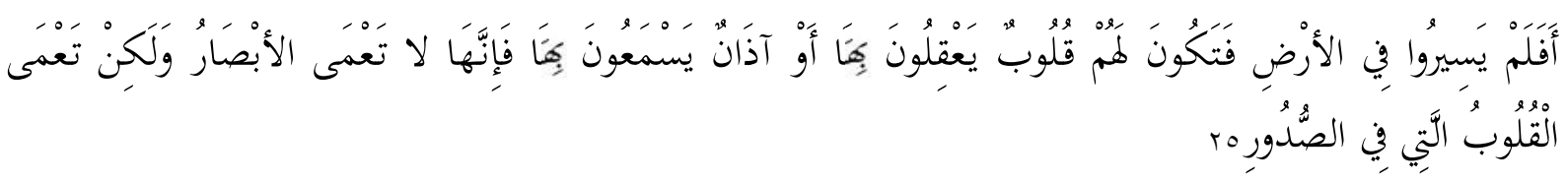

"Maka apakah mereka tidak berjalan di muka bumi, lalu mereka mempunyai hati yang dengan itu mereka dapat memahami atau mempunyai telinga yang dengan itu mereka dapat mendengar? Karena sesungguhnya bukanlah mata itu yang buta, tetapi yang buta adalah hati yang di dalam dada".

Perintah untuk mengkaji dan memahami sejarah merupakan bagian yang tak terpisahkan dari pendekatan al-Quran. Ciri-ciri penting logika sejarah Islam dinyatakan melaui ayat-ayat al-Quran. Allah berfirman:

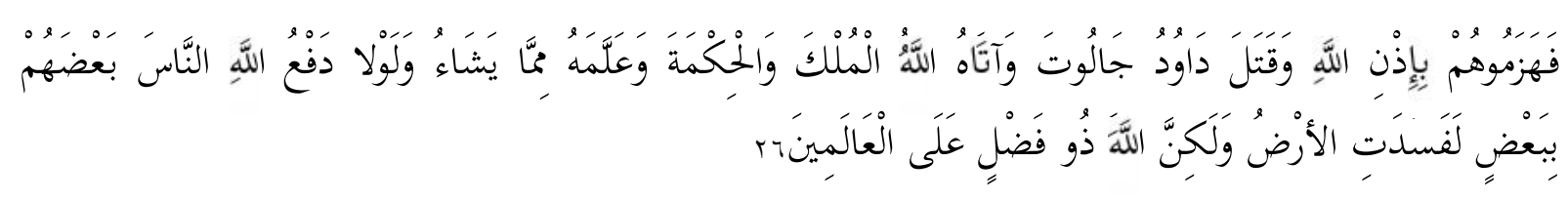

\footnotetext{
${ }^{21}$ Ibid., 44-45.

22 al-Quran, 3: 137.

${ }^{23}$ Ibid., 2: 138.

${ }^{24}$ Ibid., 22: 45.

${ }^{25}$ Ibid., 22: 46.

${ }^{26}$ Ibid., 2: 251.
} 
"Seandainya Allah tidak menolak (keganasan) sebahagian manusia dengan sebahagian yang lain, pasti rusaklah bumi ini. Tetapi Allah mempunyai karunia (yang dicurahkan) atas semesta alam".

Ayat-ayat tersebut akan membantu kita memahami bahwa ada perjuangan yang harus dilakukan antara yang benar dan yang salah di dunia ini. Dunia ekonomi sangat terkait dengan perjuangan ini, karena inilah yang mewujudkan semua kepentingan meterial umat manusia. Kita, Yousri Ahmed mengingatkan, harus memahami bahwa upaya membangun ekonomi Islam berdasarkan keadilan, kerjasama, altruisme, dan sebagainya akan mendapat perlawanan dan rintangan dari kekuatan-kekuatan yang tidak menghargai nilai-nilai etis ini. ${ }^{27}$

Dalam merumuskan pendekatan sejarah modern, menurut Yousri Ahmed, kita harus mengambil manfaat dari pengalaman ekonomi Islam masa lalu dan zaman ini. Islam memiliki sejarah selama empat belas abad. Umat Islam harus mengkaji dan memahami bagaimana negara atau bangsa Islam tumbuh dengan subur dari dari abad ke-8 sampai abad ke-15 dan secara bertahap mengalami kejatuhan. Upaya ini bisa dilakukan dengan meninjau ulang buktibukti historis, baik di tingkat makro dan mikro. Peristiwa-peristiwa ini harus diselidiki dan diteliti secara cermat untuk mencari penjelasan ilmiah dan mengindetifikasi faktor-faktor yang menentukan kemajuan dan kemunduran ekonomi. Kita, menurut Yousri Ahmed, juga harus mengkaji dan mengevaluasi pengalaman ekonomi Islam modern. Untuk memulainya, Yousri Ahmed menyarankan mengkaji bank Islam yang mulai berdiri awal tahun 1970 tersebut. Banyak pelajaran bisa dipetik dari pengalaman ini saat diselidiki dalam konteks historis. Memahami penyebab keberhasilan dan kegagalan lembaga keuangan ini selama tiga puluh tahunan yang lalu tersebut akan sangat bermanfaat untuk membangun prestasi ekonomi Islam di masa sekarang dan masa depan. ${ }^{28}$

\section{Komitmen pada Pendekatan Ilmiah dan Daya Terap (Applicability) Ekonomi Islam}

Yousri Ahmed berpendapat bahwa keberhasilan penerapan pemikiran ekonomi Islam dalam tataran praktis bergantung pada komitmen yang kuat terhadap pendekatan ilmiah. Menurut dia, membahas aturan-aturan syariah dalam lingkup ekonomi Islam tidaklah cukup. Ada suatu kebutuhan untuk menjelaskan dan mentransformasikan aturan-aturan syariah tersebut ke dalam postulat. Analisis ekonomi terhadap berbagai persoalan dan fenomena bisa dimulai hanya setelah postulat dapat dirumuskan. Berpikir bahwa kita bisa mengandalkan secara langsung syariah untuk merumuskan kebijakan ekonomi adalah pandangan yang menyesatkan. Pemikiran seperti ini mungkin tidak hanya mengantarkan kepada kegagalan menyelesaikan persoalan ekonomi, tetapi juga menyulitkan penyelesaian persoalan-persoalan ekonomi tersebut. Krisis akan muncul dan menghambat perkembangan ekonomi Islam, jika para fuqaha berpikir bahwa mereka dapat memainkan peranan sebagai ekonom. ${ }^{29}$

\footnotetext{
${ }^{27}$ Abdel Rahman Yousri Ahmed, “Methodological Approach”, 46-47.

${ }^{28}$ Ibid., 47.

29 Para fuqaha>yang tertarik pada ilmu ekonomi menawarkan paradigma baru dengan menasihati ekonomekonom Islam tentang aturan-aturan syariah yang concern pada bidangnya dengan meninjau kembali karya ekonom-ekonom Islam dan mengeluarkan kesetujuan atau ketidakpesepakatannya tentang penggunaan dan penyelewengan aturan-aturan syariah dalam karya tersebut. Ekonom Islam, di satu sisi, tidak seharusnya memainkan peran sebagai fuqaha>mereka harus mempertahankan profesi dan berunding dengan mereka yang tertarik dengan karyanya dan secara hati-hati mempertimbangkan nasihat dan pendapatnya.
} 
Yousri Ahmed memberikan contoh terkait zakat misalnya. ada kepercayaan umum bahwa prinsip-prinsip hukum Islam yang ada cukup memadai untuk memperkenankan pemerintah di dunia muslim untuk secara sukses mengumpukan zakat dan mendistribusikannya. Menurut Yousri Ahmed, ini adalah tidaklah tepat. Memang benar, bahwa penerima dan sumber zakat ditetapkan di dalam al-Quran dan Sunnah dan bahwa kita tidak diperbolehkan membuat penilaian sendiri apa yang sudah jelas dinyatakan dalam sumber-sumber hukum Islam tersebut. Namun, sebelum diterapkan, kita perlu memberikan definisi ekonomi yang jelas tentang kaum miskin, yang membutuhkan, dan penerima zakat lainnya dalam dunia modern. Kita juga membutuhkan kriteria yang jelas untuk menentukan zakat tentang perusahaan, jasa, dan aktivitas modern lainnya yang tidak disebutkan di dalam sumber-sumber asli syariah. Lebih jauh, prinsip-prinsip pengumpulan dan pendistrubusian zakat perlu dibicarakan secara ekstensif oleh ekonom-ekonom Islam bersama-sama dengan para ahli hukum Islam. Mereka perlu menerjemahkan dan merumuskan kembali prinsipprinsip ini sesuai dengan kondisi ekonomi kontemporer dan kebutuhan keuangan dalam kerangka syariah. Kerjasama ilmiah antara ekonom Islam dan ahli hukum Islam sangatlah penting. Zakat menjadi salah satu intrumen yang menaruh perhatian tidak hanya individuindividu, tetapi juga mempengaruhi seluruh aktivitas ekonomi (kekayaan, pendapatan, distribusi, dan pertumbuhan). ${ }^{30}$

Yousri Ahmed melihat bahwa sebelum tahun 1970-an pengalaman empiris ekonomi Islam belum ada, sehingga tidak ada kesempatan bagi para peneliti untuk menggunakan metode deduksi. Apa akibatnya? Para ekonom Islam sangat mengandalkan metode induksi. Apa akibat lanjutannya? Penelitian ekonomi Islam secara umum bersifat normatif.

Sangatlah penting, bagi Yousri Ahmed, untuk menyadari bahwa perkembangan ilmiah ekonomi Islam pada tahap awal (setelah Perang Dunia II) perlu menggunakan metode deduksi, misalnya merumuskan postulat sebagai premis dengan kesimpulan logis dari nilai dan aturan-aturan hukum Islam. Kemudian, kita mengandalkan postulat-postulat tersebut sebagai premis untuk menganalisis persoalan ekonomi dunia Muslim dan menarik kesimpulan aturan-aturan umum yang bisa menjelaskan persoalan-persoalan ekonomi tersebut. Metodologi ini, menurut Yousri Ahmed, akan membantu peneliti ekonomi Islam untuk mencari solusi Islam normatif atas persoalan ekonomi kita dan mengorbitkan peranan ekonomi Islam dalam masyarakat Islam modern.

Akan tetapi, sejak tahun 1970-an kondisi telah berubah di banyak negara muslim. Bankbank Islam telah dibangun. Pemerintah, di samping lembaga-lembaga non-pemerintah terlibat pengumpulan dan penyaluran pendapatan zakat. Perkembangan ini memberikan kesempatan para ekonom Islam untuk meneliti pengalaman aktual dan mengevaluasinya secara empiris dengan menciptakan dan menguji hipotesis-hipotesis yang berbeda. Upaya induktif secaman ini akan membantu membangun dan mengembangkan penerapan ekonomi Islam di dunia muslim dan dunia non muslim.

Kemajuan penerapan ekonomi Islam positif, menurut Yousri Ahmed, masih berjalan lambat karena kondisi yang tidak menguntungkan. Contoh kondisi yang tidak menguntungkan dapat ditemukan pada pemberlakuan hukum sekuler di negara-negara Islam yang mempertahankan transaksi berbasis riba (bunga) dan fatwa dari beberapa ulama yang

\footnotetext{
${ }^{30}$ Abdel Rahman Yousri Ahmed, "Methodological Approach”, 47-49.
} 
menganggap bunga sama dengan keuntungan yang diizinkan oleh syariah. Untuk kasus zakat, dan penerapan resminya, pemerintah di negara-negara muslim yang sistem pajaknya berdsarkan konsep sekuler tidak menaruh minat untuk mempelajari sistem alternatif, termasuk sistem Islam. Pemerintah di negara-negara muslim masih berpendapat bahwa pendapatan zakat masih kurang banyak dibandingkan dengan pendapatan pajak dan tidak akan menutup pengeluaran publik yang semakin meningkat. Pendapat semacam ini, menurut Yousri Ahmed, tidak pernah bisa mendukung penelitian yang serius.

Selain itu, Yousri Ahmed juga mengamati bahwa kajian pengalaman empiris ekonomi Islam dengan menggunakan pendekatan induktif juga dihambat oleh kurangnya data dari lembaga keuangan modern. Data yang tersedia dalam laporan keuangan bank Islam kurang mencukupi dan terkadang sulit dipahami. Demikian pula, lembaga non pemerintah yang mengumpulakan zakat dan mendistribuskannya di banyak negara muslim merahasiakan laporannya. Akan tetapi, keterbatasan-keterbatasan ini tidak boleh menghalangi para peneliti untuk melakukan penelitian empiris. Mereka harus melakukan kajian empiris berdasarkan pada data statistik apapun yang tersedia dan mengandalkan secara obyektif pada perkiraan yang mendekati atas apa yang tidak bisa didapat. Barangkali contoh yang bisa diajukan adalah beberapa peneliti ekonomi Islam telah melakukan penelitian empiris untuk menilai pendapatan zakat yang diharapkan di beberapa daerah dan negara-negara muslim. Mereka menggunakan metode induksi, namun mereka juga terpaksa menggunakan metode deduksi untuk menemukan beberapa fakta yang hilang tersebut.

Akibat kurangnya pengalaman empiris ekonomi Islam kontemporer, penelitian tetap fokus pada situasi ideal dan perilaku normatif yang diberikan oleh aturan dan prinsip-prinsip syariah. Penelitian ilmiah yang berpegang pada dasar ini mungkin akan menemukan kondisi ideal yang tidak bisa diterapkan, jika tidak ada kemauan sosial dan poltik yang kuat untuk menjalankan di samping alat-alat ekonomi, perubahan yang diperlukan dan keinginan mencapai cita-cita ini. Ketika ini bukan menjadi masalah, kebanyakan pemikiran teoretis yang dibuat oleh ekonom-ekonom Islam tidak akan bisa diterapkan. Celah ini masih ada, dan mungkin bertahan terus atau bahkan lebih besar. Dari sudut padang Islam, kita perlu mengajukan pertanyaan serius mungkinkah mempertahankan pendekatan ilmiah yang tidak mempunyai daya terap di dunia nyata?

Dalam kenyataan, penelitian dan analisis persoalan dalam konteks "apa yang seharusnya" yang harus berada pada "kondisi Islam yang terbaik" merupakan sesuatu yang diinginkan dan perlu sebagai bagian yang tak terpisahkan dari masyarakat dan perekonomian Islam ideal. Akan tetapi, menurut Yousri Ahmed, menyelesaikan persoalan ekonomi dalam kondisi non ideal merupakan bagian tak terpisahkan dari pendekatan Islam. ${ }^{31}$

\section{Pentingnya Dimensi Waktu dalam Analisis}

Yousri Ahmed menyadari bahwa kondisi kebanyakan negara muslim saat ini jauh dari kondisi ideal, kondisi yang sesuai dengan prinsip dan aturan-aturan syariah. Tanggung jawab untuk kembali ke syariah terletak pada semua umat Islam, namun para intelektual mempunyai peranan yang lebih penting.

\footnotetext{
${ }^{31}$ Ibid., 50.
} 
Untuk mencapai tujuan, menurut Yousri Ahmed, upaya berangsur-angsur (gradual) dalam arah yang benar menuju pencapaian cita-cita Islam sangat diperlukan. Dan ini, menurutnya, memerlukan waktu lama yang mungkin lebih dari lima atau sepuluh tahun. Dalam semangat ini, akan muncul "gerakan perbaikan" dan "gerakan perlawanan" sekaligus. Gerakan perbaikan, di satu sisi, diwakili oleh sebagaian besar masyarakat muslim yang menginginkan perubahan terjadi tanpa memahami metode untuk mencapainya dalam tataran praktis. Di sisi lain, para intelektual, para ahli, pebisnis muslim dapat memainkan peran utama untuk mencapai keinginan masyarakat dalam kerangka tujuan-tujuan syariah. Ketika gerakan perbaikan yang berorientasi Islam ini dilakukan, keberhasilan proses reformasi akan bisa dicapai. Keadaan ini akan membantu membuka jalan pembentukan lembaga-lembaga ekonomi Islam baru yang terintegrasi dan saling mendukung bersamaan dengan perjalanan waktu.

Ketika gerakan perbaikan mulai bergerak, akan ada perlawanan kuat dari "gerakan perlawanan". Gerakan penentang ini jumlahnya banyak. Namun, mereka diwakili terutama lembaga politik dan ekonomi sekuler yang memusuhi nilai-nilai Islam. Lembaga-lembaga penentang ini agak aktif dan mereka mendapatkan perlindungan kuat secara kultural dan hukum kontemporer negara-negara muslim, yang kebanyakan kasus bertentangan atau tidak sesuai dengan Syariah Islam. Selain itu, menurut Yousri Ahmed, lembaga-lembaga penentang ini mendapatkan dukungan kuat dari negara-negara non-muslim yang tidak menaruh simpati dengan prinsip-prinsip Islam.

Kecenderungan sekuler para intelektual di negara-negara muslim dan absennya pengetahuan dan pendidikan Islam di antara pebisnis muslim juga akan menghalangi reformasi Islam. Di negara-negara muslim kontemporer, kecenderungan yang mendukung gerakan perbaikan dapatlah disaksikan. Akan tetapi, menurut Yousri Ahmed, gerakan perlawanan juga ada. Mereka menunjukkan diri dan secara aktif mencoba memperlambat kemajuan islamisasi. Reaksi atas bank Islam di beberapa negara muslim telah menampilkan kesan bank-bank Islam terlihat lebih buruk daripada apa yang bank-bank yang sudah ada adalah sebuah contoh. Keadaan ini bisa dilihat dari kembalinya para nasabah, dari bank Islam ke bank konvensional.

Oleh karena itu, memiliki strategi jangka panjang untuk reformasi dan penyesuaian struktural secara berkelanjutan adalah hal penting. Strategi ini dilakukan guna implementasi oleh semua umat Islam untuk mendorong "kereta" ke arah yang benar. Apa yang penting bagi kita adalah membuat aturan-aturan yang dianggap perlu untuk penelitian ekonomi Islam dalam kerangka strategi tersebut. Komitmen ilmiah atas aturan-aturan ini tentu saja membantu dalam melakukan penelitian ekonomi Islam yang dapat diterapkan dan bermanfaat bagi umat Islam.

Ciri-ciri utama strategi perbaikan adalah dimensi waktunya. Dimensi waktu ini diharapkan memberikan periode panjang dan upaya untuk perubahan gradual dari kondisi non-Islam ke kondisi Islam. Strategi tersebut dapat dibagi ke dalam fase-fase waktu. Secara teoritis kita bisa membagi waktu untuk mencapai kondisi terbaik menjadi tiga bagian:

Pertama, Fase dłruzah. Dalam fikih Islam, beberapa kondisi pengecualian bisa muncul yang memaksa umat Islam untuk tidak mematuhi prinsip-prinsip Islam normal. Keadaan pengecualian ini disebut dłłruฉah. Pada tahap ini, ada situasi darurat yang menyebabkan boleh 
menyimpang dari aturan-aturan syariah. Kondisi semacam ini tidak bisa dihindari karena kebutuhan atau aktivitas yang sangat diperlukan. Tugas penelitian ekonomi Islam pada tahap ini, menurut Yousri Ahmed, adalah sebagai berikut:

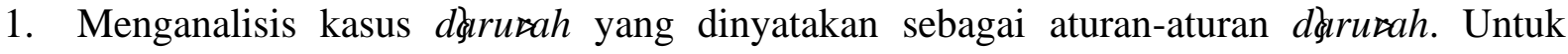
melakukan pekerjaan ini, peneliti ekonomi Islam perlu mengumpulkan sebanyak mungkin penelitian untuk masing-masing kasus. Berkonsultasi secara berkelanjutan dengan para ahli hukum Islam dan intelektual muslim sangat perlu agar keadaan dłruzah dalam persoalan ekonomi dapat digolongkan dalam kerangka hukum Islam sampai tahap ini berakhir.

2. Menuntun masyarakat yang terlibat aktivitas ekonomi dalam hal $d \not d r u \not a h$ atas solusi yang paling dekat pada syariah Islam.

3. Ketika definisi deruzah menurut syariah bersifat temporer dan tak pernah permanen, penelitian harus menentukan "lamanya waktu" tahap pertama ini. Harus jelas bahwa tahap dłru rah perlu diakhiri ketika keadaan yang lebih baik (tidak perlu kondisi terbaik) telah dicapai dari sudut syariah.

Contoh tahap dłtruฉah tersebut dapat ditemukan di negara-negara muslim di mana bankbank Islam tidak ada. Semua bank berdasarkan bunga dan banyak pebisnis berorientasi Islam meminta keterangan terkait legalitas, seperti aturan-aturan syariah, untuk mendapatkan pinjaman dari bank-bank konvensional. Mereka sadar bahwa larangan riba atau bunga dalam Islam, namun mereka menilai bahwa tidak mempunyai alternatif keuangan bebas bunga yang tersedia. Penelitian ekonomi Islam harus memperhatikan persoalan ini secara serius dan mengkaji jika keuangan bebas bunga bisa diadakan.

Contoh lain yang diberikan Yousri Ahmed adalah pembayaran pajak. Apakah pembayaran pajak dapat membebaskan dari pembayaran zakat? Pada kenyataannya, zakat berbeda dengan sistem pajak yang ada di negara-negara muslim modern. Beberapa pembayar pajak menyatakan bahwa kemampuan keuangannya tidak mengizinkan mereka menanggung beban pembayaran pajak dengan zakat pada waktu yang sama. Jika mereka menghindari pajak, pihak berwenang dapat menyita hak milik atau mungkin memenjarakannya. Apa yang mereka lakukan dan solusi apa yang bisa diberikan oleh ekonom-ekonom Islam kepada mereka hingga sistem keuangan Islam bisa dijalankan $?^{32}$ Inilah beberapa pertanyaan yang musti dijawab oleh para ekonom Islam.

Kedua, tahap menengah (the intermediate phase). Tahap menengah adalah prasyarat untuk mengimplenetasikan perubahan struktural yang diperlukan, sebagaimana yang kita lihat nanti, dalam tahap akhir, pembaharuan. Dalam tahap ini, upaya perlu dikonsentrasikan pada mempersiapkan lingkungan yang memungkinkan masyarakat untuk menerima dan mendukung prinsip-prinsip sistem ekonomi Islam. Di sinilah kegiatan-kegiatan harus diadakan sesuai dengan prinsip-prinsip syariah. Tugas penelitian ekonomi Islam pada tahap ini meliputi:

1. Pengumpulan informasi yang tepat dan data statistik yang mendukung penerapan prinsipprinsip ekonomi Islam. Dalam melakukan ini, menurut Yousri Ahmed, unsur-unsur terlemah dan terkuat harus dikenali dalam lembaga dan kegiatan ekonomi yang spesifik.

\footnotetext{
${ }^{32}$ Ibid., 54.
} 
Kemudian, kita juga perlu menghilangkan unsur-unsur terlemah dan mengindari sementara unsur terkuat untuk menghindari bentrokan.

2. Dengan memfokuskan unsur-unsur terlemah dari gerakan penentang sejak awal, metode dan kebijakan untuk transformasi gradual kegiatan ekonomi dari pola sekuler ke Islam harus dilakukan oleh para peneliti ekonomi Islam.

3. Perlunya mencari solusi atas beberapa persoalan ekonomi masyarakat muslim yang menderita akibat ekonomi konvensional. Solusi penengah dan transisional harus dikelompokkan dengan perhitungan dan pemahaman yang jelas bagaimana transisi gradual akan dibebaskan dari perilaku berdasarkan nilai-nilai dan motif sekuler positif menuju nilai-nilai dan motif berdasarkan Islam. Secara analitis, proses transisi akan lebih cepat ketika masyarakat menyadari, dan yakin akan manfaat religius dan material melalui kebangkitan kembali nilai-nilai Islam.

4. Penelitian yang tekun dan memadai untuk mengidentifikasi dan menganalisis kegiatan baru yang bisa diciptakan dalam landasan ekonomi Islam yang sempurna. Kegiatankegiatan ini akan menjadi pilar di mana proses perubahan struktural bergantung pada tahap akhir. Dalam konteks ini, prioritas ditentukan berdasarkan aktivitas berbeda dengan penelitian yang cermat tentang hal-hal penting. Faktor-faktor yang dianggap berpengaruh dalam melakukan hal tersebut menyangkut pemenuhan kebutuhan umat Islam saat ini dan kesesuainnya dengan tujuan pembangunan perekonomian Islam jangka panjang. Dengan kata lain, kepentingan masa depan dan kekuatan masyarakat muslim.

5. Prinsip-prinsip sistem ekonomi Islam harus dipublikasikan di media massa dan diajarkan kepada peserta didik, khususnya di lembaga pendidikan menegah dan atas.

Yousri Ahmed memberikan beberapa contoh tahap menengah ini. Unsur terlemah dari kekuatan yang menentang gerakan perbaikan menuju perekonomian Islam adalah monopoli yang terjadi di negara-negara muslim kontemporer. Mengumpulkan data tentang monopoli dan menyebarkan data-data tersebut kepada masyarakat perlu dilakukan. Lalu apa solusi yang bisa diberikan oleh para penggiat ekonomi Islam terkait monopoli ini? Solusinya adalah adalah kita harus membangun proyek yang menawarkan pengganti atas produksi yang dimonopoli dan menyediakan barang-barang dengan harga bersaing. Yousri Ahmed menganggap penting membangun proyek-proyek bernilai Islam dengan partisipasi sejumlah besar masyarakt agar bisa menggerakkan semangat kerjasama di antara umat Islam, menggerakkan sumber daya keuangan, dan membangun perusahaan-perusahaan besar yang akan melawan monopolis-monopolis dan mendorong mereka bersikap kompetitif. Sejumlah besar masyarakat yang bersama-sama membangun rencana baru berdasarkan syariah ini akan memberikan perlindungan dari munculnya monopoli baru dalam sistem Islam di masa depan. Penelitian ekonomi Islam harus diarahkan untuk mencari metode di mana rencana-recana ini dibangun, didanai, dan dioperasionalisasikan secara efisien untuk melawan monopolimonopoli yang kuat.

Kelemahan lainnya adalah persoalan inflasi yang mengganggu negara-negara muslim kontemporer. Pertanyaan mendesaknya di sini adalah berkaitan dengan solusi Islam terhadap persoalan ini. Mungkinkah menemukan solusi sementara pihak berwenang atau pemerintah di negera-negara tersebut masih memakai kebijakan fiskal dan moneter berbasis bunga dan sebagian besar lembaga bisnis yang ada tidak mematuhi aturan-aturan syariah? Itu pertanyaan 
yang diajukan Yousri Ahmed. Yousri Ahmed menyadari bahwa tidak mungkin ada solusi Islam yang sempurna dan ideal sebelum menghapuskan semua kebijakan dan praktik ekonomi non islami. Namun, di dalam tahap menengah menuju islamisasi ini, dia mengingatkan kita untu menemukan beberapa solusi sementara yang membantu mengurangi beban inflasi. Solusi Islam yang diharapkan mampu memecahkan persoalan inflasi di masa depan semacam ini harus disetujui atau diizinkan oleh syariah.

Contoh berikutnya yang bisa diberikan adalah pembayaran pajak yang membebani umat Islam yang sangat patuh membayar zakat. Mungkinkah mempertimbangkan usulan pada tingkat politik, yang didukung kajian ekonomi serius, untuk membuktikan bahwa keinginan masyarakat tidak akan diganggu jika pembayaran zakat dipotong dari pajak yang terkumpul? Penelitian ekonomi Islam harus dilakukan dalam rangka menemukan akibat-akibat mengganti pajak dengan zakat.

Contoh selanjunya adalah berkaitan dengan pengadopsian pendanaan bank bebas bunga di tengah kekuatan dan dominasi sistem bank berbasis bunga. Penelitian dalam tahap menengah harus diarahkan menuju penemuan metode terbaik untuk mendirikan bank-bank Islam, secara terus menerus meningkatkan efisiensi dan memperluas akitivitasnya sambil menghindari pertentangan langsung dengan bank-bank berbasis bunga konvensional. Bank dengan dua sistem bisa diterima untuk sementara, namun ini tidak seharusnya perlu meniru teknik pendanaan yang dijalankan oleh bank konvensional. Pada saat yang sama, penelitian harus membimbing bank-bank Islam terkait kebijakan yang meningkatkan kemampuan daya saing mereka dalam pasar keuangan. ${ }^{33}$

Ketiga, tahap perubahan struktural. Inilah tahap terakhir dalam upaya penerapan prinsip-prinsip syariah ke dalam perekonomian masyarakat muslim. Tahap perubahan struktural ini bisa dimulai hanya setelah penyempurnaan tahap menengah tercapai. Tahap perubahan struktural ini menekankan pentingnya penelitian ekonomi Islam berada pada kondisi terbaik. Keberhasilan yang telah dicapai dalam tahap menengah menciptakan iklim yang baik untuk pembangunan rencana yang lebih luas, lebih dari sektor perbankan, berdasarkan prinsip-prinsip Islam. Suasana yang kondusif untuk penerapan mungkin tidak berarti meringankan tugas penelitian ekonomi Islam. Namun, sebaliknya, menurut Yousri Ahmed, pada tahp ini, penelitian ilmiah masih perlu dikembangkan lagi untuk keberhasilan penerapan nilai dan prinsip-prinsip ekonomi Islam. Kesempurnaan perubahan struktural membutuhkan kajian ekonomi makro yang sungguh-sungguh dalam bidang alokasi sumber daya dan distribusi pendapatan yang adil dalam konteks syariah. Perlu juga diperhatikan dalam tahap ketiga ini, yaitu mengidentifikasi alat-alat dan kebijakan yang menghapus semua lembaga dan kegiatan-kegiatan ekonomi yang tidak sesuai dengan syariah. Penghapusan ini harus dilakukan dengan biaya sosial minimal. Penelitian juga mencari jalan memperkuat hubungan ekonomi antara negara-negara muslim dan membangun hubungan ekonomi yang seimbang dengan masyarakat non muslim dan negara-negara berdasarkan syariah.

\section{Kesimpulan}

Dari pembahasan di atas, penulis dapat menarik beberapa kesimpulan. Perlu diketahui bahwa ekonomi Islam tidak sama dengan aturan-aturan fiqh terkait transaksi keuangan,

\footnotetext{
${ }^{33}$ Ibid., 54-56.
} 
kontrak, dan zakat, sebagaimana yang dipikirkan ahli-ahli hukum Islam. Demikian juga, ekonomi Islam tidak dibatasi hanya pada persoalan-persoalan utama, misalnya zakat dan riba, sebagaimana yang dikatakan oleh beberapa ekonom Islam. Jangkauan ekonomi Islam lebih luas, seluas kajiannya terhadap persoalan-persoalan ekonomi yang yang berdasarkan nilainilai syariah Islam. Secara metodologis, komitmen semacam ini harus terwujud ke dalam bentuk paduan antara aturan-aturan syariah dan nilai-nilai Islam ke dalam postulat atau aksioma. Penyelesaian berbagai persolan, proses analisis ekonomi, dan perumusan aturanaturan yang menjelaskan ekonom Islam, harus berdasarkan pada postulat atau aksiomaaksioma tersebut.

Membangun teori ekonomi Islam merupakan upaya tak terpisahkan dengan membangun paradigma baru. Pengalaman empiris ekonomi Islam adalah syarat wajib untuk merumuskan teori empiris. Ketiadaan pengalaman empiris ekonomi Islam tidak harus menghalangi ekonom-ekonom Islam. Pendekatan deduktif digunakan sebagai pengganti. Teori Islam normatif yang berdasarkan pendekatan deduktif diperlukan dalam tahap awal islamisasi untuk menuntun umat Islam menuju perilaku yang seharusnya, perilaku yang sesuai dengan prinsipprinsip syariah. Ketika pengalaman empiris ekonomi Islam sudah ada, pendekatan empiris bisa digunakan. Teori yang dirumuskan sebelumnya bisa diverifikasi diterima, ditolak, atau dikualifikasi. Pendekatan deduktif dan postulat normatif yang akan selalu digunakan dalam merumuskan teori ekonomi Islam, bahkan ketika mengadopsi metode empiris, perlu ditekankan. Ini karena hubungan yang tidak terlelakkan antara ekonomi Islam dan aturan atau etika Islam.

Dari sudut pandang metodologis, sebagaimana yang sudah dijelaskan di atas, teori ilmiah apapun terdiri atas tiga unsur utama, yaitu definisi atau terminologi, postulat (aksioma atau asumsi), dan hipotesis. Dari perspektif Islam, definisi dan postulat yang disusun dan dibuat sesuai dengan nilai-nilai Islam dan syariah, perlu dipastikan untuk memastikan karakter hipotesis Islam yang berujung pada karya teoretis.

Pengalaman historis ekonomi Islam di masa lalu akan sangat membantu ekonomi Islam modern. Tentu saja, beberapa pelajaran dapat diambil dari pengalaman ini. Namun yang paling penting untuk analisis ekonomi adalah menemukan logika dari perspektif Islam. Banyak ayat al-Quran memberikan sumber inspirasi dalam hal ini.

Poin penting lainnya yang bisa disimpulkan dari pembahasan di atas adalah daya terap ekonomi Islam yang sangat bergantung pada pemakaian metodologi yang benar dalam merumuskan teori. Upaya para peneliti untuk meminimalisasi atau menghapuskan celah antara teori dan persoalan aktual masyarakat muslim juga sangat diperlukan. Dalam konteks ini, kita perlu menyadari bahwa persoalan ini akan mengalami perubahan dalam waktu lama yang sangat dibutuhkan untuk transisi dari perekonomian umat Islam saat ini menuju Islamisasi. Periode transisi ini dapat dibagi menjadi tiga tahap, yaitu tahap dłruฉah, menengah, dan tahap perubahan struktural. Keberhasilan penerapan ekonomi Islam akan bergantung pada pengkajian persoalan khusus dari masing-masing tahap dan bergantung pada solusi yang tepat dari perspektif Islam.

\section{Daftar Rujukan}

Addas, Waleed A.J. Methodology of economics: secular vs Islamic. Malaysia: International 
Islamic University Press, 2008.

Ahmed, Abdel Rahman Yousri. "Methodological Approach to Islamic Economics: Its Philosophy, Theoretical Construction and Applicability" dalam Habib Ahmed (ed). Theoretical Foundation of Islamic Economics. Jeddah: Islamic Development Bank, 2002.

Bagus, Lorens. Kamus Filsafat. Jakarta:Gramedia Pustaka Utama, 2000.

Keraf, A. Sonny dan Mikhael Dua. Ilmu Pengetahuan: Sebuah Tinjauan Filosofis. Yogyakarta: Kanisius, 2001.

Partanto, Pius A. dan Al-Barry, M. Dahlan. Kamus Ilmiah Populer. Surabaya: Penerbit Arkola, 1994.

Surajiyo. Filsafat Ilmu dan Perkembangannya di Indonesia, cet-7. Jakarta: Bumi Aksara, 2013.

T. Gilarso. Pengantar Ilmu Ekonomi Makro. Yogyakarta: Kanisius, 2004.

http://www.financepractitioner.com/contributor-biographies/abdel-rahman-yousri-ahmad.

http://www.hbku.edu.qa/en/staff/abdelrahman-yousri-abdelrahman. 